\title{
Comparison of in vitro-cultured and wild-type Perkinsus marinus. I. Pathogen virulence
}

\author{
Susan E. Ford ${ }^{1, *}$, Marnita M. Chintala ${ }^{2}$, David Bushek ${ }^{3}$ \\ ${ }^{1}$ Haskin Shellfish Research Laboratory, Institute of Marine and Coastal Sciences, Rutgers University, 6959 Miller Avenue, \\ Port Norris, New Jersey 08349, USA \\ ${ }^{2}$ United States Environmental Protection Agency (US EPA), Office of Research and Development (ORD), National Health and \\ Environmental Effects Laboratory (NHEERL), Atlantic Ecology Division, 27 Tarzwell Drive, Narragansett, Rhode Island \\ 02882, USA \\ ${ }^{3}$ Baruch Marine Field Laboratory, Belle W. Baruch Institute for Marine Biology and Coastal Research, \\ University of South Carolina, PO Box 1630, Georgetown, South Carolina 29442, USA
}

\begin{abstract}
Perkinsus marinus is a highly contagious pathogen of the eastern oyster Crassostrea virginica. Until recently, transmission studies have employed wild-type parasites isolated directly from infected oysters. Newly developed methods to propagate P. marinus in vitro have led to using cultured parasites for infection studies, but results suggest that cultured parasites are less virulent than wild-type parasites. In this paper, we report results of experiments designed to quantify differences between wild-type and cultured $P$. marinus virulence and to test the following hypotheses: (1) in vitro-cultured parasites are less virulent than wild-type parasites; (2) virulence decreases gradually during in vitro culture; (3) virulence of in vitro cultures can be restored by in vivo passage; (4) virulence changes with culture phase. Our results demonstrate that parasites freshly isolated from infected hosts are much more virulent than those propagated in culture, indicating a potential deficiency in the culture medium used. Virulence was lost immediately in culture and, for that reason, the practice of repassing cultured cells through the host to restore virulence does not work for $P$. marinus. Virulence was also associated with culture phase: log-phase parasites were significantly more virulent than those obtained from lag- or stationary-phase cultures.
\end{abstract}

KEY WORDS: Disease $\cdot$ Parasite $\cdot$ Oyster $\cdot$ Crassostrea virginica $\cdot$ Loss of virulence $\cdot$ Culture phase

\section{INTRODUCTION}

Since its discovery in the late 1940s (Mackin et al. 1950), Perkinsus marinus has been recognized as a highly contagious pathogen of the eastern oyster Crassostrea virginica. From the beginning, transmission studies using parasites isolated directly from infected oysters were used to gain an understanding of the disease process (Ray 1954, Andrews \& Hewatt 1957, Mackin \& Sparks 1962, Valiulis \& Haskin 1972). Recent techniques developed to propagate $P$. marinus in culture (Gauthier \& Vasta 1993, Kleinschuster \& Swink 1993, La Peyre et al. 1993) have opened new possibili-

*E-mail: susan@hsrl.rutgers.edu ties for infection studies using this parasite (Bushek \& Allen 1996, Bushek et al. 1997).

The ability to infect hosts with pathogens under controlled conditions is an important tool in the study of disease. The availability of continuous in vitro pathogen cultures provides substantially greater experimental ease and flexibility compared to using pathogens that must be isolated from naturally infected hosts. Use of cultured pathogens in disease studies implies that they possess, to an adequate degree, significant biological characteristics of naturally occurring parasites. In the case of Perkinsus marinus, tolerance of cultured parasites to acute salinity change does parallel, reasonably well, that seen in nature (Burreson et al. 1994), as does growth 
at different temperatures (Dungan \& Hamilton 1995, Gauthier \& Vasta 1995); however, the same does not appear true for virulence, the degree to which the pathogen causes disease. Studies using P. marinus isolated from infected oysters have shown that lethal infections can be generated with as few as 50 to 100 parasites injected into the shell cavity (Mackin \& Sparks 1962, Valiulis \& Haskin 1972, Chu \& Volety 1997). Further, in repeated experiments, Ray (1954) obtained deaths in about $30 \mathrm{~d}$ when oysters were fed tissue minces of highly infected oysters. In contrast, Bushek et al. (1997) were unable to establish infections in oysters by feeding them up to $10^{7}$ cultured parasites. When the same concentration was injected into the shell cavity, infections developed, but no oysters died during a 2 mo experiment. Similarly, La Peyre et al. (1993) found only light infections after 8 wk when $10^{6}$ cultured parasites were injected into the shell cavity. Gauthier \& Vasta (1993), on the other hand, reported heavy infections in 4 to $5 \mathrm{wk}$, followed by mortality, after 2 biweekly shell-cavity injections of $2 \times 10^{5}$ P. marinus.

Loss of virulence in cultured pathogens is well known. One possible contributing factor is the culture phase. Morphologically different forms of Perkinsus marinus occur in oysters (Mackin \& Boswell 1955) and most of these have been observed in vitro (La Peyre et al. 1993) where their relative proportion is associated with culture phase (Bushek 1994). Virulence of other pathogens is affected by culture phase (da Silva \& Sacks 1987, Wozencraft \& Blackwell 1987, Rey et al. 1990), so it is reasonable to believe the same might be true for $P$. marinus. Another important factor is likely to be the number of passages that a culture has undergone. Viruses, bacteria, and protozoans have all been reported to lose the ability to cause disease after a certain number of passages in culture (Giannini 1974, Chang \& Fish 1983, Moody et al. 1990, Kallinikova et al. 1992, Hassan et al. 1996, Mukhopadhyay et al. 1998). For some pathogens, virulence can be maintained in a cultured line if it is repassed periodically through its host (Faulkner et al. 1976, Todd et al. 1995).

Chang \& Fish (1983) cautioned against generalizing the results obtained using in vitro-cultured parasites until similarities and differences between cultured and wild-type parasites have been documented. In this paper, we report results from a series of experiments designed to quantify virulence differences between wild-type and cultured Perkinsus marinus and to test the following hypotheses: (1) in vitro-cultured P. marinus are less virulent than wild-type $P$. marinus; (2) virulence decreases gradually during in vitro culture; (3) virulence can be restored by in vivo passage; (4) virulence changes with culture phase.

\section{MATERIALS AND METHODS}

Oysters. Hatchery-reared Crassostrea virginica, highly susceptible to Perkinsus marinus, were obtained from Mook SeaFarms, Damariscotta, Maine, USA. All groups were produced and reared under similar conditions, and within each batch, all oysters were the same year class. They were shipped overnight to the Haskin Shellfish Research Laboratory where they were maintained in the laboratory at $10^{\circ} \mathrm{C}$ and $25 \mathrm{ppt}$ in $1 \mu \mathrm{m}$-filtered sea water (FSW) before the start of each experiment. Maintenance at $10^{\circ} \mathrm{C}$ was intended to reduce metabolic activity while oysters were being held for varying periods before challenge experiments. At the start of each experiment, 10 to 20 oysters were assayed using a total-body parasite-burden procedure, to determine whether they were free of $P$. marinus (see later subsection 'Sample processing' and Table 1). Before and during each experiment, oysters were fed a daily maintenance diet of approximately $2 \times 10^{6}$ cells oyster $^{-1}$ of a 2:1 mixture of Isochrysis spp. and Chaetoceros spp. All experiments were conducted in FSW at 26 to $28^{\circ} \mathrm{C}$ and $25 \mathrm{ppt}$. Water was aerated and changed weekly. Wastewater was treated with household bleach (minimum $10 \mathrm{ppm}$ residual $\mathrm{Cl}_{2}$ ) for at least $24 \mathrm{~h}$ prior to disposal. All experiments were terminated after $84 \mathrm{~d}$, except the culture-phase trial, which ended at Day 87.

Expt I. Wild-type vs cultured Perkinsus marinus. Two experiments were performed to measure differences in virulence between wild-type and in vitrocultured $P$. marinus. Wild-type parasites were isolated from Delaware Bay native oysters in September 1994 (autumn trial) and July 1995 (summer trial). The collections allowed us to compare not only the differences between wild-type and cultured parasites, but between wild-type cells isolated at seasons when in vivo parasite growth rates are very rapid (July) and after they have peaked (September). Parasites from 2 different in vitro cultures were used to test whether results were unique to a single cultured-parasite line. Oyster mortality rates and parasite burdens of oysters living at the end of the experiment were determined. Comparisons were made according to parasite type (wild-type vs cultured) and season of isolation of wildtype parasites.

Isolation of wild-type Perkinsus marinus: P. marinus were isolated from naturally infected Delaware Bay oysters using the procedure of La Peyre \& Chu (1994). Oyster tissues ( $\mathrm{N}=35$ for the autumn trial and $\mathrm{N}=27$ for the summer trial) were minced and placed in $0.2 \mu \mathrm{m}$-filtered sea water containing penicillin and streptomycin sulfate (SIGMA cell culture product $\mathrm{P}-0781$ ) to a final concentration of $100 \mathrm{U}$ penicillin and $100 \mu \mathrm{g}$ of streptomycin $\mathrm{ml}^{-1}$ (FSW-PS). Approximately 
Table 1. Crassostrea virginica. Shipment and initial sampling dates, and initial measurements of Maine oysters used in experiments. Values are means (SEM); \#P. m. $\mathrm{g}^{-1}$ wwt: no. of Perkinsus marinus $\mathrm{g}^{-1}$ oyster wet $\mathrm{wt}$; \# $\geq$ P. m. $\mathrm{g}^{-1}$ wwt/\# samp.: ratio no. of oysters with 1 or more $P$. marinus $\mathrm{g}^{-1}$ wet wt to no. of oysters sampled. Parasites could have been acquired at the Haskin Laboratory between arrival and sampling dates; however, a density of $1 P$. marinus $\mathrm{g}^{-1}$ wwt is considered within the bounds of identification error

\begin{tabular}{|lcccccccc|}
\hline Expt & $\begin{array}{c}\text { Arrival } \\
\text { date } \\
(\mathrm{m} / \mathrm{d} / \mathrm{yr})\end{array}$ & $\begin{array}{c}\text { Sampling } \\
\text { date } \\
(\mathrm{m} / \mathrm{d} / \mathrm{yr})\end{array}$ & $\begin{array}{c}\# P . \mathrm{m} . \\
\mathrm{g}^{-1} \mathrm{wwt}\end{array}$ & $\begin{array}{c}\# \geq 1 \mathrm{P} . \mathrm{m} . \\
\mathrm{g}^{-1} \mathrm{wwt} / \\
\# \mathrm{samp} .\end{array}$ & $\begin{array}{c}\text { Shell } \\
\text { height } \\
(\mathrm{mm})\end{array}$ & $\begin{array}{c}\text { Total } \\
\text { wt } \\
(\mathrm{g})\end{array}$ & $\begin{array}{c}\text { Estimated } \\
\text { tissue wt } \\
(\mathrm{g})\end{array}$ & $\begin{array}{c}\text { Pre-expt } \\
\text { holding time } \\
(\mathrm{d})\end{array}$ \\
\hline I: Cultured vs Wild-type cells & & & & & & & \\
Autumn trial & $9 / 9 / 94$ & $9 / 20 / 94$ & $0.76(0.34)$ & $1 / 10$ & $53.0(0.6)$ & $13.0(0.39)$ & $7.8(0.2)$ & 10 \\
Summer trial & $6 / 28 / 95$ & $6 / 29 / 95$ & $0.31(0.12)$ & $1 / 10$ & $85.4(7.8)$ & $82.9(15.1)$ & $22.1(4.6)$ & 14 \\
II: In vitro passage & & & & & & & & \\
Passage 1 & $1 / 10 / 95$ & $1 / 20 / 95$ & $0.98(0.74)$ & $1 / 10$ & $74.3(5.4)$ & $62.4(10.4)$ & $16.7(2.8)$ & $17-30$ \\
Passage 5 & $1 / 10 / 95$ & $1 / 20 / 95$ & $0.98(0.74)$ & $1 / 10$ & $74.6(7.7)$ & $63.0(11.9)$ & $16.8(3.1)$ & $47-57$ \\
Passage 9 & $3 / 29 / 95$ & $3 / 30 / 95$ & $0.17(0.06)$ & $0 / 20$ & $74.6(5.8)$ & $64.0(10.4)$ & $14.6(2.4)$ & $13-14$ \\
III: In vivo passage & $5 / 4 / 95$ & $5 / 19 / 95$ & $0.56(0.19)$ & $1 / 10$ & $72.8(5.9)$ & $56.4(9.2)$ & $15.1(2.4)$ & 19 \\
IV: Culture stage & $1 / 10 / 95$ & $1 / 25 / 95$ & $0.98(0.74)$ & $1 / 10$ & $75.0(0.6)$ & $64.5(0.91)$ & $17.1(0.3)$ & 60 \\
\hline
\end{tabular}

$25 \mathrm{ml}$ of this solution was used for every gram wet weight $\left(\mathrm{g}^{-1} \mathrm{wwt}\right)$ of oyster tissue. The tissues were then homogenized in a blender and filtered through a series of Nitex screens: 230, 183, 130, 80, 41 and $15 \mu \mathrm{m}$. The filtrate was placed in $50 \mathrm{ml}$ tubes and centrifuged at $50 \times g$ for $10 \mathrm{~min}$. The supernatant, containing the parasites, was decanted into another set of $50 \mathrm{ml}$ tubes, then centrifuged at $800 \times g$ for 20 min and washed with $0.2 \mu \mathrm{m}$ FSW-PS a total of 5 times. The pellet, now containing the parasites, was resuspended in $10 \mathrm{ml} 0.2 \mu \mathrm{m}$ FSW-PS. Four $1 \mathrm{ml}$ samples of this suspension were placed in sterile glass tubes containing $5 \mathrm{ml}$ of Ray's fluid thioglycollate medium (RFTM) and incubated at room temperature $\left(22\right.$ to $\left.28^{\circ} \mathrm{C}\right)$ overnight to promote parasite enlargement for easier counting. The remaining sample was refrigerated at $4^{\circ} \mathrm{C}$ to block cell proliferation. The room-temperature-incubated parasites were counted the following morning using a hemacytometer. Parasites in the remaining, refrigerated sample were adjusted to the desired density using $0.2 \mu \mathrm{m}$ FSW-PS (see subsection 'Oyster dosing and maintenance' below).

In vitro cultures: Cultured parasites used in the autumn trial were from a high (>30)-passage Delaware Bay isolate (ATCC 50509). The culture was initiated in March 1993 using prezoosporangia obtained after RFTM incubation (La Peyre \& Faisal 1995) and maintained in continuous culture (Bushek 1994). A subculture was stored at $15^{\circ} \mathrm{C}$ prior to use for this experiment. Cultures for the summer trial were started using parasites isolated from the hemolymph of Long Island Sound oysters that had been exposed to natural infections in lower Delaware Bay as part of the in vitropassage phase of this study (Culture LX-4, see later subsection for Expt II). Parasites were placed directly in medium recommended for Perkinsus marinus, hereinafter referred to as 'Dungan's medium' (Bushek et al.
2000), and grown at $28^{\circ} \mathrm{C}$. Parasites were harvested for inoculation while they were in log-phase growth.

Oyster dosing and maintenance: Samples in the autumn and summer trials were treated as follows:

Autumn trial: 40 oysters were challenged by wildtype parasites and 40 by cultured cells. Each oyster was numbered, then weighed in air and under water. The difference, considered an estimate of wet tissue weight (Andrews 1961), was used to weight-standardize the dose administered to each individual. This experiment was conducted in conjunction with an investigation of parasite delivery methods; thus doses were administered in 1 of 4 ways: feeding (parasites mixed with a daily algal diet); mantle cavity injection (concentrated parasites injected into the shell cavity through a notch in the shell margin); adductor muscle injection (parasites injected into the adductor muscle hemolymph sinuses); or intubation (parasites introduced into the mouth) (see Chintala et al. 2002 for detailed methods). For each parasite type-delivery method combination, 10 oysters were each dosed with $10^{6}$ P. marinus $\mathrm{g}^{-1} \mathrm{wwt}_{\text {; }} 10$ oysters not exposed to Perkinsus marinus served as controls.

Summer trial: 48 oysters were assigned to each of the 2 treatment groups (wild-type or cultured parasites). Each oyster was weighed and numbered, and its wet tissue weight was estimated using regression equations obtained from subsamples of the experimental oysters. We found that underwater weighing was a less accurate measure of oyster wet tissue weight because it consistently overestimated the meat weight of the oysters by including the mantle fluid ( $18 \%$ of total weight). Each oyster was injected into the shell cavity with $10^{6} \mathrm{P}$. marinus $\mathrm{g}^{-1}$ wwt. The oysters were maintained in 151 buckets each holding 12 oysters injected with the same parasite type, with 4 buckets per treatment; 5 oysters not dosed with 
$P$. marinus were maintained in a separate bucket as controls.

Expt II. Effect of in vitro passage. The effect of in vitro passage on the virulence of Perkinsus marinus was measured in a series of 3 trials in which cultured parasites that had been passed 1, 5, and 9 times were injected into the shell cavity of experimental oysters. Of necessity, injections of the different passages had to be made at different times. As a control for possible seasonal or other metabolic changes in the experimental oysters during the course of the experiment, which could be confused with changes in the parasites during culture, $P$. marinus were cryopreserved immediately after establishment in culture and used in parallel challenges. The cryopreserved parasites were intended to represent the initial culture, before the first passage.

Isolation and culture of Perkinsus marinus: New cultures of $P$. marinus were established from Isolate LX-4 (isolation date = 12 December 1994), which was established using $P$. marinus from Long Island Sound oysters that been held in Delaware Bay for several weeks. Thus, the oysters were possibly exposed to $P$. marinus in both Long Island Sound and Delaware Bay. Hemolymph $(1 \mathrm{ml})$ was withdrawn from the adductor muscle of each of 4 oysters. The hemolymph from each oyster was aliquoted equally into 4 sterile $15 \mathrm{ml}$ tubes containing $10 \mathrm{ml}$ of 25 ppt $0.1 \mu \mathrm{m}$ FSW-PS. The tubes were centrifuged 3 times $(200 \times g, 100 \times g$, and $75 \times g)$ for $5 \mathrm{~min}$ and the pellet resuspended after each centrifugation in the FSW-PS. After the final wash, cells in each tube were resuspended in $10 \mathrm{ml}$ of Dungan's medium and aseptically transferred to individual $25 \mathrm{~cm}^{2}$ Falcon T-flasks. Each culture was treated with penicillin-streptomycin sulfate (100 U final conc.) and amphotericin B (0.25 $\mu \mathrm{g} \mathrm{ml}^{-1}$ final conc.) and maintained at $22^{\circ} \mathrm{C}$.

During the roughly $1 \mathrm{mo}$ in which the cultures took to begin proliferating well, they were not passed (we define a passage as removal of $90 \%$ of the cells and 10 -fold dilution of the remaining $10 \%$ with fresh Dungan's medium), but merely 'fed' by two $50 \%$ medium changes. After they had begun proliferating, the volume of each culture was increased to $50 \mathrm{ml}$ by the addition of medium, and then split equally into 5 culture flasks. The volume of medium in each culture flask was then increased to $50 \mathrm{ml}$. This was considered the initial culture. The in vitro-cultured parasites were demonstrated to be Perkinsus marinus using molecular genetic tools (Reece et al. 2001). Once the cultures were in log-growth phase ( 4 to $5 \times 10^{6}$ cells ml ${ }^{-1}$ ), $15 \mathrm{ml}$ from each flask were cryopreserved (see following subsection).

Parasites in the remaining $35 \mathrm{ml}$ of medium in each flask proliferated to a density of $10^{7}$ cells ml ${ }^{-1}$. Prolifer- ation slowed at this density, indicative of the stationary phase, and cultures were passed for the first time. Because the protocol required 2 injections $1 \mathrm{wk}$ apart, 2 culture flasks were established at the time of passage. The first flask was placed at $28^{\circ} \mathrm{C}$ and used to inject oysters $24 \mathrm{~h}$ after the dilution. The second flask was kept at $15^{\circ} \mathrm{C}$ and used $7 \mathrm{~d}$ after the passage to inject the oysters a second time. Parasites for the first injection were harvested in the late-lag/early-log phase and those for the second injection were harvested in the late-log/early-stationary phase. Parasites in the 3 remaining flasks were grown continuously at $22^{\circ} \mathrm{C}$ and passed when densities reached $10^{7} \mathrm{cells} \mathrm{ml}^{-1}$. These subcultures were then used during Passages 5 and 9 as described for Passage 1.

Cryopreserved parasites: Log-phase parasites were harvested from the initial culture by removing $15 \mathrm{ml}$ from each flask to a sterile centrifuge tube. The cells were pelleted for $5 \mathrm{~min}$ at 300 to $400 \times g$ and resuspended to approximately $10^{6}$ parasites $\mathrm{ml}^{-1}$ in freezing medium (Dungan's medium with 10\% [v/v] FBS and $10 \%$ [v/v] DMSO). A $1 \mathrm{ml}$ aliquot was pipetted into each of 75 cryopreservation tubes, which were placed in polyfoam trays and frozen at $-80^{\circ} \mathrm{C}$.

The parasites were resurrected 3,27 , and $69 \mathrm{~d}$ postfreezing to use as initial-culture parallels to the passed cells. The tubes were first thawed rapidly in a $37^{\circ} \mathrm{C}$ water bath until just liquid, then cells were transferred aseptically to $15 \mathrm{ml}$ centrifuge tubes. Dungan's medium was added slowly (beginning 1 drop at a time) for 10 to $15 \mathrm{~min}$ until the volume reached $10 \mathrm{ml}$. The gradual addition of medium was to prevent rupture of thawing cells (Freshney 1987). The parasites were carefully mixed and centrifuged at $100 \times g$ for $10 \mathrm{~min}$; $9 \mathrm{ml}$ of medium was removed and replaced with another $9 \mathrm{ml}$ of medium containing $100 \mathrm{U}$ penicillin and $100 \mu \mathrm{g}$ streptomycin sulfate $\mathrm{ml}^{-1}$. The cells were then transferred to T-flasks at $28^{\circ} \mathrm{C}$ and the volume of medium increased to $50 \mathrm{ml}$. Viability of resurrected parasites was estimated at each time of resurrection using neutral red dye uptake. The cultures reached injection densities in about $2 \mathrm{wk}$.

Oyster dosing and maintenance: For each of the 3 passages tested, 48 oysters were dosed with passed parasites and 48 with cryopreserved parasites. Each oyster was given 2 shell-cavity injections, 1 wk apart, using $10^{6}$ parasites $\mathrm{g}^{-1}$ wwt injection ${ }^{-1}$. It was not always possible to have the passed and cryopreserved cells at the desired culture phase at the same time. Consequently, intervals between parallel cryopreserved- and passed-cell injections were staggered by 1 (Passage 9), 10 (Passage 5) and 13 (Passage 1) days Oysters were maintained in 151 buckets, each containing 12 oysters injected with the same parasite type, with 4 buckets per treatment. Five oysters, not exposed 
to Perkinsus marinus, were maintained in a separate bucket as controls.

Expt III. Effect of in vivo passage. The high $(>30)$ passage isolate (ATCC 50509), was delivered to 24 hatchery-reared oysters from Maine via 2 shell-cavity injections of $10^{6}$ parasites $\mathrm{g}^{-1}$ wwt each, $1 \mathrm{wk}$ apart. The oysters were held in two $15 \mathrm{l}$ buckets for $60 \mathrm{~d}$ to allow the parasites to proliferate. Perkinsus marinus were reisolated from the oysters, re-established in culture, and the parasites harvested for injection as soon as they had reached log phase.

A different set of Maine oysters was challenged with $10^{6}$ Perkinsus marinus $\mathrm{g}^{-1}$ wwt of either the high-passage isolate or the in vivopassed culture. Parasites of each type were administered to separate groups of 48 oysters via 2 shell-cavity injections 1 wk apart. Oysters were placed in $15 \mathrm{l}$ buckets, each holding 12 oysters injected with parasites from 1 culture type, with 4 buckets per treatment. Five oysters, not exposed to $P$. marinus, were maintained in a separate bucket as controls.

Expt IV. Effect of culture phase. Oysters were injected with parasites from Passage 4 of the LX-4 culture that was in 1 of 3 growth phases: lag, log, or stationary. Lag-phase parasites were used $24 \mathrm{~h}$ after a $90 \%$ medium dilution. Microscopic inspection indicated that the cultures were predominantly single, quartet or octet cells with refringent vacuoplasts (Fig. 1A). Log-phase cultures were used $4 \mathrm{~d}$ after a $90 \%$ dilution, and contained small cells, large single cells, clumps of dividing cells, and large cells rupturing into clusters of daughter cells (Fig. 1B). Once cultures reached the stationary phase $\left(10^{7}\right.$ cells $\left.\mathrm{ml}^{-1}\right)$ they were maintained for an additional 4 wk with approximately weekly $50 \%$ medium changes. These cultures were dominated by small cells, many in clusters, and contained groups of apparently senescent cells (identified as nonrefractive, dark cells by phase-contrast microscopy: Fig. 1C).

Parasites from each phase were administered via a single shell-cavity injection to 30 oysters, at $10^{6}$ Perkinsus marinus $\mathrm{g}^{-1}$. The oysters were then placed in $15 \mathrm{l}$ buckets, each holding 10 oysters injected with the same culture-phase parasites, 3 buckets per treatment; 2 replicate buckets of 10 oysters not injected with $P$. marinus were maintained as controls. On Day 3 post-injection, 12 oysters from each of the experimental treatments and 6 control oysters were assayed for total-body parasite burdens.
A similar number was sampled at the end of the experiment, $87 \mathrm{~d}$ later.

Sample processing. Oysters were inspected daily. Dead oysters were removed and recorded, and the tissues weighed and assayed for parasite burden. At the
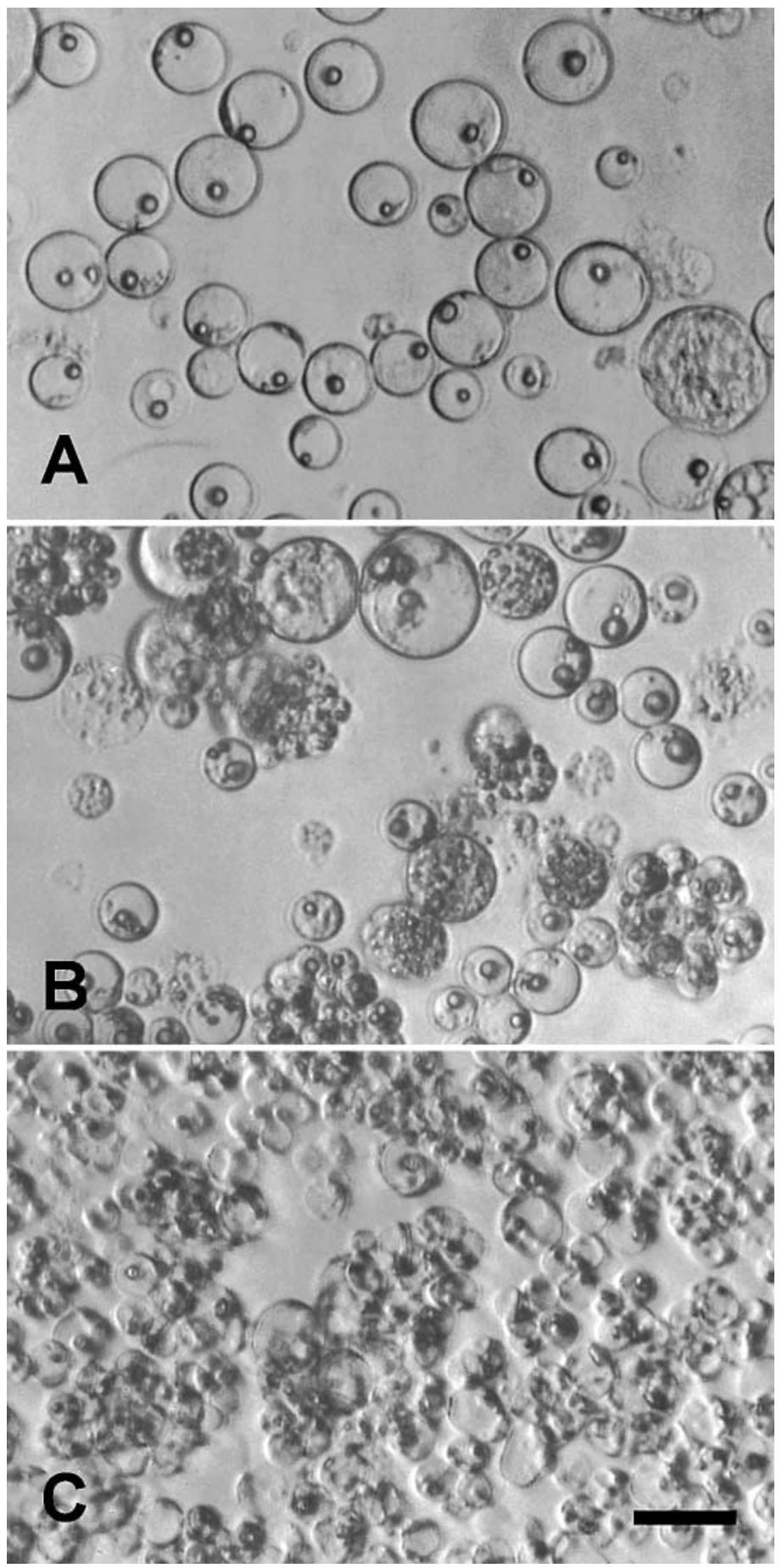

Fig. 1. Perkinsus marinus. Photomicrographs (Hoffman modulation contrast) of parasites in (A) lag phase, (B) log phase, and (C) stationary phase cultures. Scale bar $=25 \mu \mathrm{m}$ 
end of each experiment, all surviving oysters were shucked, and the tissues weighed and assayed for parasite burdens. Total-body parasite burdens were estimated according to the methods of Bushek et al. (1994), modified as described in Fisher \& Oliver (1996). In the body burden assay, the entire soft tissue mass of each oyster is minced and incubated in RFTM, which causes the parasite to enlarge (Ray 1952). The enlarged 'hypnospore' stages are freed from oyster tissues with $\mathrm{NaOH}$, washed, and concentrated (Choi et al. 1989). The resulting parasite suspension is aliquoted and 3 to 4 subsamples counted. If subsample counts are $<20$, the entire suspension is counted. Final counts are expressed as parasites $\mathrm{g}^{-1} \mathrm{wwt}$.

In addition to analyzing survival time and parasite burdens, we combined the 2 parameters into a single 'virulence index' (VI). Briefly, each oyster was scored from 0 to 5 according to when it died and what its final parasite burden was; the 2 scores were summed and a

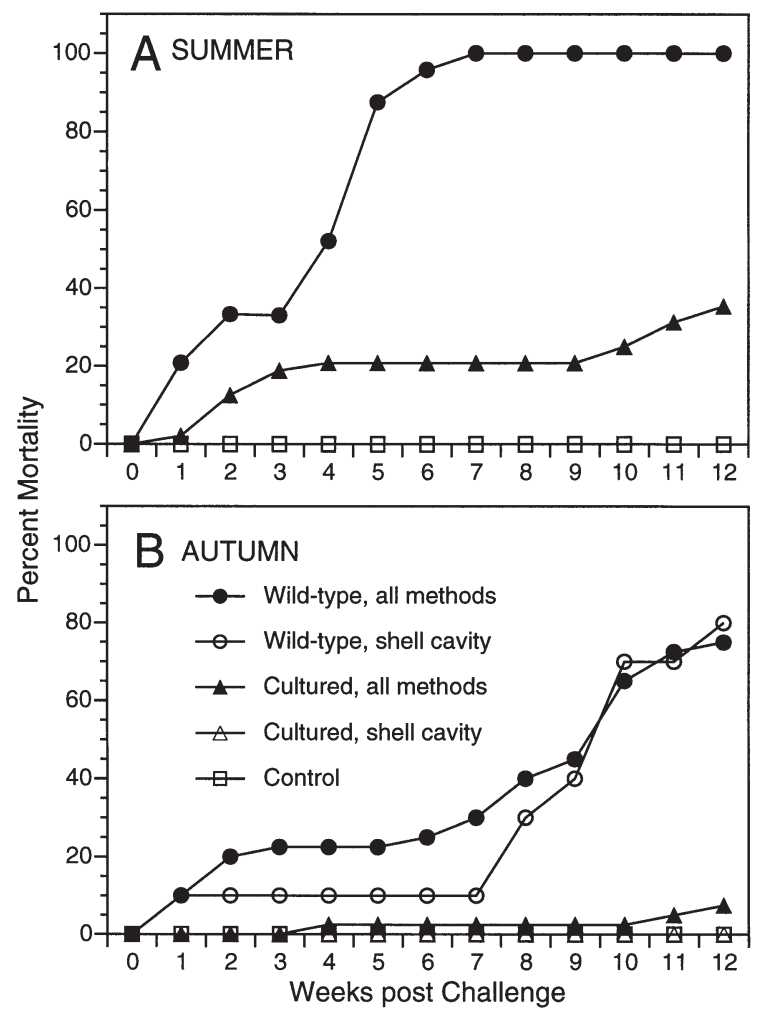

Fig. 2. Crassostrea virginica. Cumulative mortality of susceptible eastern oysters, challenged with wild-type and cultured Perkinsus marinus using wild-type cells isolated in (A) July and (B) September. The summer trial used shell-cavity injection only, whereas the autumn trial involved several dosing methods, including shell-cavity injection (see text). (A) Starting $N=48$ for each experimental group and 5 for the uninjected controls. (B) Starting $\mathrm{N}=40$ for each experimental group, all dosing methods combined, 10 for the shell-cavityinjected only group, and 10 for the nonchallenged controls sample mean calculated for each treatment (see Chintala et al. 2002, this issue, for details). This allowed us to compare treatments that otherwise were difficult to analyze using survival time or parasite burden alone because of disparate numbers (i.e. treatments with few survivors against those with many survivors.)

Statistics. Comparisons of mortality among treatments within each experiment were made using nonparametric survival analysis (Mantel-Cox log-rank test (Abacus Concepts 1994)). Parasite densities were transformed $\left(\log _{10}[x+1]\right)$ and subjected to analysis of variance (ANOVA) using a general linear model (SAS Institute 1990). The virulence indices were also examined by ANOVA. Where buckets, rather than individual containers, were used to hold oysters, buckets were nested within the treatment factor of the ANOVA. The Bonferroni post-hoc test was used for pairwise comparisons. Tissue weights were similarly analyzed to determine whether differences in weight-specific parasite burdens were associated with changes in soft-tissue weight. Differences between means were considered significant at $\alpha=0.05$. Controls were not included in the models because the hypotheses we were testing were between treatment types, not between treatments and controls. ANOVA tables are presented for complex results; otherwise, only the level of significance is given.

\section{RESULTS}

\section{Wild-type vs cultured cells}

Mortality

In the summer trial, all the oysters dosed with wildtype Perkinsus marinus were dead by Week 7 postinjection (Fig. 2A). At the same time, mortality was $20 \%$ in oysters injected with cultured parasites and it rose to only $35 \%$ by the end of the experiment. Overall mortalities were lower in the autumn trial, but the difference associated with cell type was large (Fig. 2B). When considered without regard to dosing method, final mortality was 10 times higher (75 vs $7.5 \%$ ) in the oysters infected with wild-type $P$. marinus cells than in those dosed with cultured cells. A plot of only those oysters dosed via the shell cavity (data directly comparable to those for the summer trial in which all oysters were dosed this way) showed essentially the same pattern and the extent of mortality (Fig. 2B).

The cumulative mortality pattern in both experiments, especially for the wild-type-parasite injected oysters, showed an early phase and a later phase. The early phase began within the first week after challenge and lasted for 2 to $3 \mathrm{wk}$. The late phase began between 
Weeks 3 and 4 for oysters injected with wild-type parasites in the summer trial, but not until Week 7 for oysters in the autumn trial. In both trials, the second phase for oysters injected with cultured parasites began 9 to 11 wk after injection and was continuing when the experiment ended.

\section{Parasite burdens}

Infection prevalence was $100 \%$ in all challenged live and dead oysters in both trials. Because there were 2 apparent mortality episodes, we compared parasite burdens for oysters dying during the early episode, those dying during the later one, and those surviving to the end of the experiment. This factor, which we termed 'timing', was analyzed in separate ANOVAs for each parasite type. Timing was significant only for wild-type Perkinsus marinus ( $\mathrm{p}=0.0230$ in the summer

Table 2. Crassostrea virginica. Means (SEM) virulence index and parasite burdens $\left(\log _{10}[x+1]\right.$ cells $\left.\mathrm{g}^{-1} \mathrm{wwt}\right)$ comparisons between cultured and wild-type Perkinsus marinus, and results of the Bonferroni post-hoc analysis of parasite burdens in oysters. Bonferroni comparisons of parasite burdens were made separately for cultured and wild-type cells in each trial. Groups with same letter are not significantly different from each other within each parasite (cultured or wild-type) grouping. Early deaths occurred $\leq 3$ wk post-challenge; late deaths occurred $>3$ wk post-challenge

\begin{tabular}{|c|c|c|}
\hline Treatment & $\mathrm{N}$ & Mean (SEM) \\
\hline \multicolumn{3}{|l|}{ I: Summer trial } \\
\hline \multicolumn{3}{|l|}{ Cultured parasites } \\
\hline Virulence index & 48 & $4.19(0.336)$ \\
\hline \multicolumn{3}{|l|}{ Parasite burdens } \\
\hline Early dead & 0 & - \\
\hline Late dead & 3 & $5.36(1.867) \mathrm{a}$ \\
\hline Survivors & 35 & $4.68(0.234) \mathrm{a}$ \\
\hline \multicolumn{3}{|l|}{ Wild-type parasites } \\
\hline Virulence index & 48 & $7.31(0.308)$ \\
\hline \multicolumn{3}{|l|}{ Parasite burdens } \\
\hline Early dead & 9 & $3.22(0.159) \mathrm{a}$ \\
\hline Late dead & 21 & $6.71(0.141) b$ \\
\hline Survivors & 10 & $5.35(0.305) \mathrm{C}$ \\
\hline \multicolumn{3}{|l|}{ II: Autumn trial } \\
\hline \multicolumn{3}{|l|}{ Cultured parasites } \\
\hline Virulence index & 38 & 3.37 (0.215) \\
\hline \multicolumn{3}{|l|}{ Parasite burdens } \\
\hline Early dead & 10 & $4.72(0.446) \mathrm{a}$ \\
\hline Late dead & 6 & $5.77(0.374) \mathrm{a}$ \\
\hline Survivors & 32 & $4.14(0.238) \mathrm{a}$ \\
\hline \multicolumn{3}{|l|}{ Wild-type parasites } \\
\hline Virulence index & 40 & $5.65(0.292)$ \\
\hline \multicolumn{3}{|l|}{ Parasite burdens } \\
\hline Early dead & 16 & $5.06(0.263) \mathrm{a}$ \\
\hline Late dead & 32 & $6.05(0.112) \mathrm{b}$ \\
\hline Survivors & 0 & - \\
\hline
\end{tabular}

trial, and 0.0001 in the autumn trial; Table 2). 'Timing' was not a significant factor in the results of culturedparasite injections, largely because most of the oysters were still alive at the end of the experiment. Although control oysters had light parasite burdens (mean = $10^{2.5} \mathrm{~g}^{-1} \mathrm{wwt}$ ), these were 2 or more orders of magnitude lower than in experimental oysters.

\section{Virulence index}

In both summer and autumn trials, the virulence index (VI) for wild-type parasites was significantly higher than that for cultured parasites (Table 2). The ANOVA for the summer trial showed a significant bucket effect, as well as an effect of cell type (Table 3), due probably to spawning and a temporary failure of the air supply early in the experiment, which varied from bucket to bucket. In the autumn trial, both dosing method and parasite type had a significant effect on the VI (Chintala et al. 2002), but the interaction term was not significant (Table 4).

\section{Effect of passage in vitro}

\section{Mortality}

Cumulative mortalities for oysters injected with parasites from different passages were very low $(<5 \%)$ in Passages 1 and 9 and moderate $(\leq 20 \%)$ in Passage 5 (Fig. 3). The passages were not significantly different

Table 3. Crassostrea virginica. ANOVA results for virulence index of summer trial comparing wild-type with cultured Perkinsus marinus cells. Oysters were held in buckets and dosed by shell-cavity injection

\begin{tabular}{|lrrrrc|}
\hline Source & df & Type III SS & \multicolumn{1}{c}{ MS } & \multicolumn{1}{c|}{$F$} & $\mathrm{p}$ \\
\hline Cell type & 1 & 234.375 & 234.375 & 13.13 & 0.0111 \\
Bucket (cell) & 6 & 107.125 & 17.854 & 4.33 & 0.0007 \\
Error & 88 & 362.500 & 4.119 & & \\
\hline
\end{tabular}

Table 4. Crassostrea virginica. ANOVA results for virulence index of autumn trial comparing wild-type with cultured Perkinsus marinus cells. Oysters were held in individual containers and dosed with 1 of 4 methods (feeding, intubation, or shell-cavity or adductor muscle injection)

\begin{tabular}{|lrrrrc|}
\hline Source & df & Type III SS & \multicolumn{1}{c|}{ MS } & \multicolumn{1}{c|}{$F$} & $\mathrm{p}$ \\
\hline Dosing & 3 & 53.519 & 17.839 & 8.75 & 0.0001 \\
Cell type & 1 & 107.673 & 107.673 & 52.79 & 0.0001 \\
Dosing $\times$ Cell & 3 & 2.073 & 0.691 & 0.34 & 0.7973 \\
Error & 70 & 142.775 & 2.039 & & \\
\hline
\end{tabular}




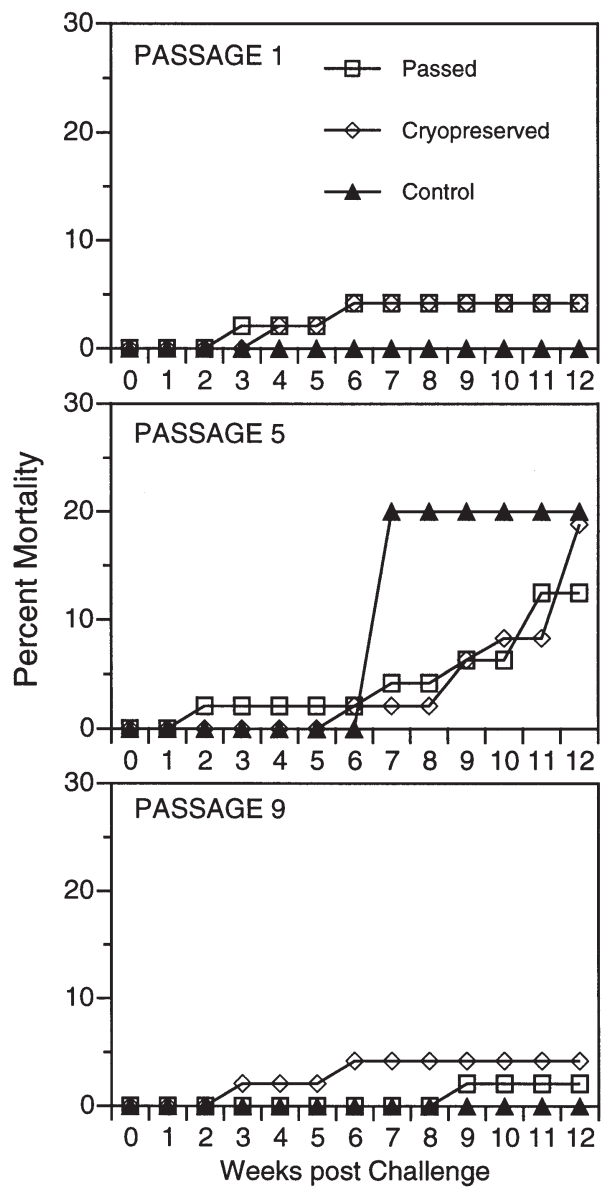

Fig. 3. Crassostrea virginica. Cumulative mortality of susceptible oysters challenged with Perkinsus marinus from Passages 1,5 , and 9 of the same in vitro culture. For each passage, a parallel set of oysters was injected with $P$. marinus that had been cryopreserved when first established in culture (i.e. had not been passed through culture) and a set of control oysters remained uninjected. In each passage trial, starting $\mathrm{N}=$ 48 each for passed and cryopreserved group, and 5 for uninjected control groups

from each other or from the controls. The high mortality of the Passage 5 control treatment is biased by low sample size $(\mathrm{N}=5$ control oysters versus $\mathrm{N}=48$ for each treatment). Within each trial, mortalities were statistically similar in groups dosed with passed and cryopreserved parasites.

\section{Parasite burdens}

Infection prevalence was $100 \%$ in all challenged live and dead oysters. Mean parasite burdens in survivors were uniformly low (means of $\leq 10^{3.3} \mathrm{~g}^{-1}$ wwt: Fig. 4A), and although there were significant differences associated with passage and parasite-type combination, the differences followed no clear pattern (see following subsection 'Virulence index'). Parasite burdens of oysters that died during the experiment were higher, but still relatively low (10 to $10^{5} \mathrm{~g}^{-1}$ wwt) compared to those for dead oysters in other experiments. In Passage 5, which had the highest mortality, most of the dead oysters had parasite burdens of less than $10^{4} \mathrm{~g}^{-1}$ wwt. During trials for the first and fifth passages, 5 and $11 \%$, respectively, of the oysters developed a conchiolin deposit on the inner shell, somewhat resembling that of 'juvenile oyster disease' (Bricelj et al. 1992). Survival analysis showed that mortality was weakly associated with the presence of this deposit in Passage $1(\mathrm{p}=$ 0.040 ), but very strongly associated in Passage 5 ( $p<$ 0.0001).

Control oysters, including the single oyster that died, had negligible parasite burdens $\left(<10^{0.7} \mathrm{~g}^{-1} \mathrm{wwt}\right)$, which were 1 to 3 orders of magnitude lower than in experimental oysters. A 2-way ANOVA showed no significant
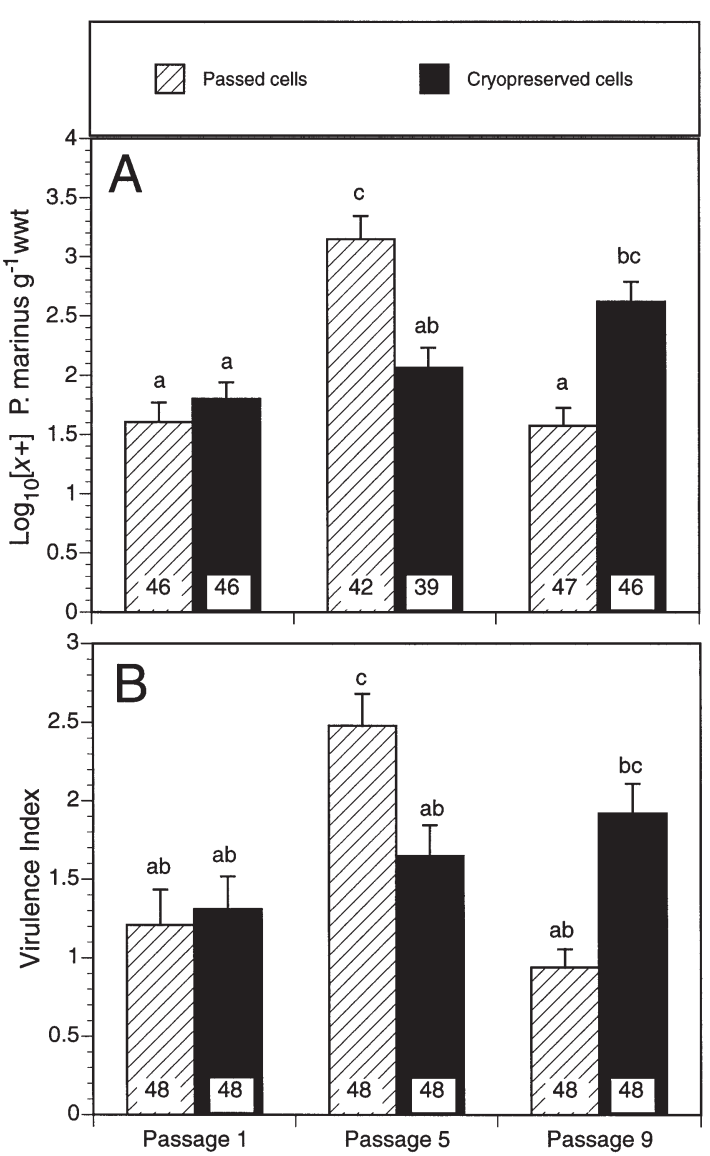

Fig. 4. Crassostrea virginica. (A) Mean Perkinsus marinus concentrations in tissues of oysters surviving on Day 84 of the in vitro-passage experiment. (B) Virulence index for all oysters in the in vitro-passage experiment. Error bars represent standard errors of the mean; numbers at bottom of bars represent number of oysters assayed; letters above bars represent results of Bonferroni mean comaparison: means with the same letters are not significantly different 
Table 5. Crassostrea virginica. ANOVA results for virulence index comparing oysters injected with Perkinsus marinus cells that had been passed 1, 5, or 9 times, or had been cryopreserved without passage. Oysters were held in buckets

\begin{tabular}{|lrrrrc|}
\hline Source & df & Type III SS & MS & \multicolumn{1}{c|}{$F$} & $\mathrm{p}$ \\
\hline Passage & 2 & 34.395 & 17.197 & 17.82 & 0.0007 \\
Bucket (passage) & 9 & 8.687 & 0.965 & 0.53 & 0.8521 \\
Cell type & 2 & 0.500 & 0.500 & 0.27 & 0.6006 \\
Passage $\times$ Cell type & 273 & 39.437 & 19.718 & 10.83 & 0.0001 \\
Error & & 496.979 & 1.820 & & \\
\hline
\end{tabular}

effect of passage number or parasite type (passed or cryopreserved) on the wet weights of surviving oysters, indicating that differences in weight-specific parasite loads were not caused by changes in weight.

\section{Virulence index}

In vitro passage had a significant effect on the VI, and the interaction term of passage and parasite type was also significant (Table 5). A Bonferroni test comparing the means of each of the 6 passage-cell type combinations, however, revealed no particular pattern to the differences (Fig. 4B). Parasites from Passages 9 and 1 had the lowest VI, and those from Passage 5 had the highest. In contrast, the VI means for cryopreserved cells increased over successive passage trials, but were not statistically different. The VI ranking for the 6 experimental groups was the same as that for parasite burdens (cf. Fig. 4A and B) and also similar to mortality patterns (Fig. 3).

Although cryopreserved cells lost viability with increasing storage time (viability was 23 to 58,14 to 28 , and 4 to $7 \%$, respectively after 3,27 , and $69 \mathrm{~d}$ at $-80^{\circ} \mathrm{C}$ ), the lack of differences among the cryopreserved-cell trials indicates that this loss had no significant effect on virulence. Similarly, none of the differences among treatments were related to the staggering of cryopreserved and passed-cell injections.

\section{Effects of repassage in vivo}

\section{Mortality}

Cumulative mortality among oysters injected with a high passage culture and a culture that had been just passed through an oyster and re-established in culture was $<10 \%$, with no deaths until the last $3 \mathrm{wk}$ of the experiment (Fig. 5). There were no significant differences between the treatments. None of the uninjected control oysters died during the experiment.

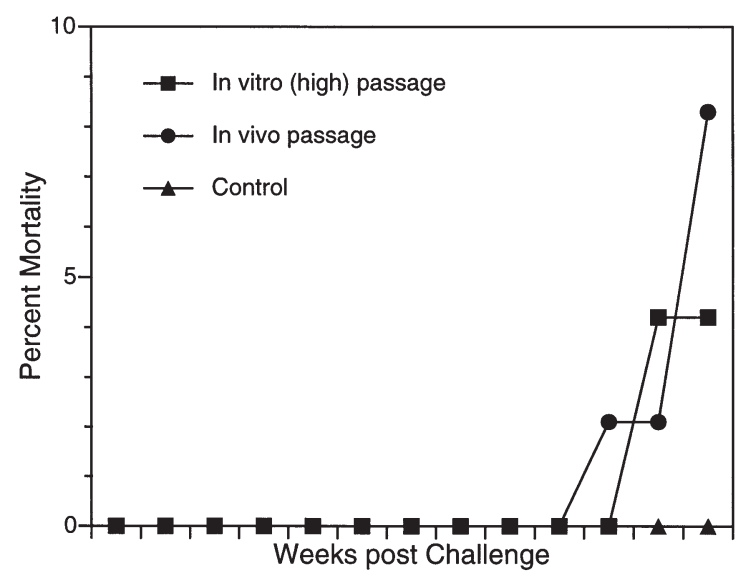

Fig. 5. Crassostrea virginica. Cumulative mortality of susceptible oysters injected with Perkinsus marinus from a high (>30)-passage in vitro culture and with parasites from the same culture that had been passed in vivo through oysters and then re-established in culture. Starting $\mathrm{N}=48$ each for the experimental groups and 5 for the uninjected controls

Parasite burdens

Infection prevalence was $100 \%$ in all challenged live and dead oysters. There was no significant effect of passage type (in vivo vs in vitro) parasite burdens in oysters surviving at the end of the experiment (Table 6). Parasite burdens in the few oysters that died during the experiment were between $10^{6}$ and $10^{7} \mathrm{~g}^{-1}$ wwt.

Control oysters had negligible parasite burdens (mean $<10^{0.2} \mathrm{~g}^{-1} \mathrm{wwt}$ ) at the end of the experiment, which were nearly 4 orders of magnitude lower than in experimental oysters. There was no significant effect of treatment on tissue weight of surviving oysters $(\mathrm{p}=$ $0.507)$.

Table 6. Crassostrea virginica. Means (SEM) for virulence index and parasite burden $\left(\log _{10}[x+1]\right.$ cells $\mathrm{g}^{-1}$ wwt, survivors only) comparisons among oysters injected with cultured Perkinsus marinus from a high (>30)-passage culture and those from the same culture that had been passed through the host before re-establishment in culture. There were no significant differences between the 2 treatments means for either measure

\begin{tabular}{|lcccc}
\hline \multirow{2}{*}{ Treatment } & \multicolumn{2}{c}{ Virulence index } & \multicolumn{2}{c}{ Parasite burden } \\
& $\mathrm{N}$ & Mean (SEM) & $\mathrm{N}$ & Mean (SEM) \\
\hline $\begin{array}{l}\text { High in vitro- } \\
\text { passage parasites }\end{array}$ & 48 & $2.60(0.170)$ & 46 & $3.68(0.191)$ \\
$\begin{array}{l}\text { In vivo- } \\
\text { passed parasites }\end{array}$ & 48 & $3.13(0.197)$ & 44 & $4.15(0.177)$
\end{tabular}




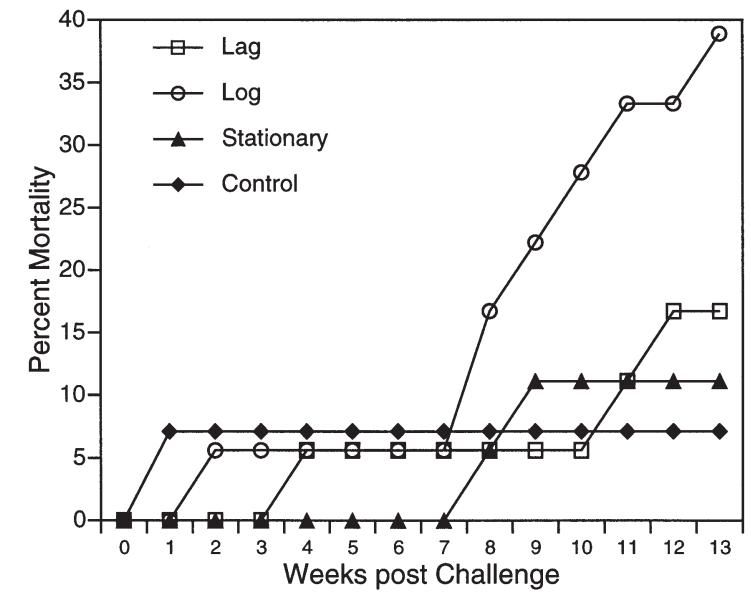

Fig. 6. Crassostrea virginica. Cumulative mortality of susceptible oysters into whose shell cavity 1 of 3 culture phases of Perkinsus marinus had been injected. Starting N = 30 for each of the 3 culture-phase groups and 20 for the uninjected controls

\section{Virulence index}

A 1-way ANOVA showed no significant difference between the VI of in vitro- and in vivo-passed cells (Table 6).

\section{Effect of culture phase}

Mortality

Oysters injected with log- and lag-phase parasites, as well as controls, experienced some initial mortality (Fig. 6). No further deaths occurred in controls, but a second episode of mortality began after Week 7 in oysters injected with log-phase cells and after Week 10 in oysters inoculated with lag-phase parasites. Oysters dosed with stationary-phase parasites had no initial mortality, but began dying after Week 7. Cumulative mortality at the end of the experiment was 38, 16, 11, and $7 \%$ for log-, lag-, and stationary-phase parasite treatments and controls, respectively. There was no statistically significant association of mortality with culture phase.

\section{Parasite burdens}

Infection prevalence was $100 \%$ in all challenged live and dead oysters. A 2-way ANOVA showed a significant effect of culture phase, and a significant interaction between phase and day of collection ( 3 or 87 ) on parasite burdens (Table 7). The Bonferroni test found no significant differences associated with culture phase on Day 3, but on Day 87 oysters injected with
Table 7. Crassostrea virginica. ANOVA results for parasite burdens $\left(\log _{10}[x+1] \mathrm{g}^{-1}\right.$ wwt) comparisons according to Perkinsus marinus culture phase (lag, log, or stationary) and day (3 or 87 ) of sampling

\begin{tabular}{|lrrrcc|}
\hline Source & df & Type III SS & MS & $F$ & $\mathrm{p}$ \\
\hline Phase & 2 & 14.985 & 7.492 & 9.36 & 0.0143 \\
Bucket (phase) & 6 & 4.804 & 0.801 & 0.75 & 0.6108 \\
Day & 1 & 1.801 & 1.801 & 1.69 & 0.1982 \\
Phase $\times$ Day & 2 & 10.095 & 5.047 & 4.73 & 0.0120 \\
Error & 66 & 70.366 & 1.066 & & \\
\hline
\end{tabular}

log-phase parasites had significantly higher burdens than those injected with stationary-phase cells (Fig. 7). Between Days 3 and 87, parasite densities increased, decreased, and remained unchanged in oysters challenged with log-phase, stationary-phase, and lagphase cells, respectively. The mean parasite burden of dead oysters challenged with log-phase cells was $10^{6.7} \mathrm{~g}^{-1} \mathrm{wwt}$, whereas the means for those injected with lag- and stationary-phase cells were $10^{0.5}$ and $10^{2.9} \mathrm{~g}^{-1} \mathrm{wwt}$, respectively.

Control oysters had negligible parasite burdens (mean $\leq 10^{0.8} \mathrm{~g}^{-1} \mathrm{wwt}$ ) at the end of the experiment, which were 3 to 5 orders of magnitude lower than experimental oysters. Between Days 3 and 87, the mean wet meat weight in surviving oysters declined $38 \%$, from 12.5 to $7.8 \mathrm{~g}(\mathrm{p}<0.0001)$, but there was no significant effect of culture phase $(p=0.460)$.

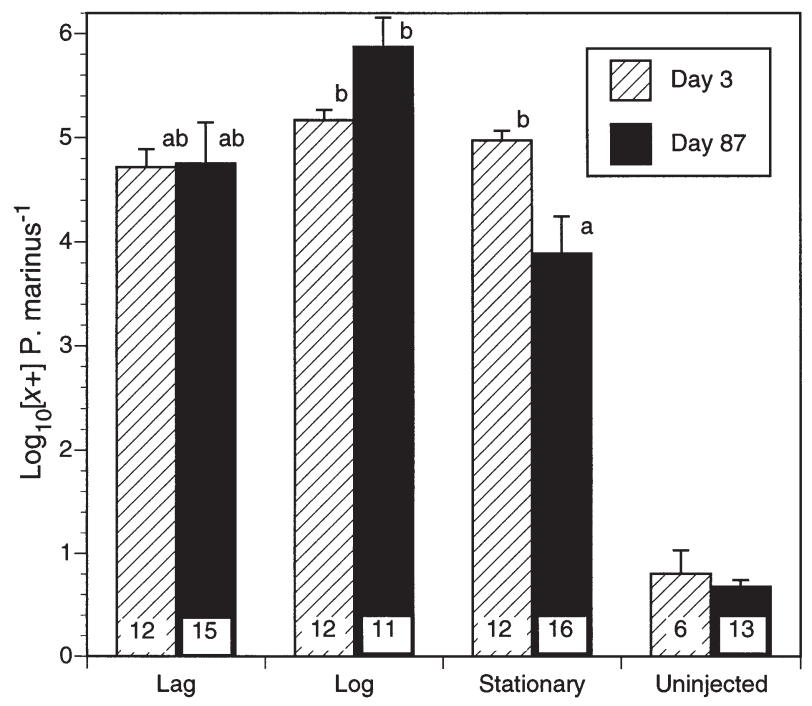

Fig. 7. Crassostrea virginica. Mean Perkinsus marinus concentrations in tissues of live oysters sampled at Days 3 and 87 post-challenge with 3 culture phases of the parasite. Error bars represent standard errors of the mean. Numbers at bottom of bars represent number of oysters assayed; letters above bars represent results of Bonferroni mean comparison: means with the same letters are not significantly different 
Table 8. Crassostrea virginica. Means and standard errors for virulence index comparison among oysters injected with Perkinsus marinus from different culture phases (oysters chosen for Day 87 sampling only), and results of Bonferroni post hoc analysis. Groups with same letter are not significantly different from each other

\begin{tabular}{|lcc|}
\hline Culture phase & $\mathrm{N}$ & Mean (SEM) \\
\hline Lag & 17 & $3.17(0.294) \mathrm{a}$ \\
Log & 18 & $5.00(0.333) \mathrm{b}$ \\
Stationary & 18 & $2.41(0.258) \mathrm{a}$ \\
\hline
\end{tabular}

Virulence index

Because of the nature of the index, which includes mortality, the VI was calculated only for the Day 87 collection. The effect of culture phase on the index was highly significant $(\mathrm{p}<0.001)$ and a Bonferroni post-hoc test indicated that the value for log-phase cells was significantly higher than that for lag- or stationaryphase cells, which were statistically similar (Table 8).

\section{DISCUSSION}

Virulence is a measure of the ability of a pathogen to invade, proliferate in, and cause disease in a host (Tanada \& Fuxa 1987, Osterhout 1999) and is measured by the effect it has on a host, usually as an infection development or mortality rate. Virulence is an inherent quality of the pathogen even though it may appear to vary because of changes in a parasite's environment, either within or outside of the host. The present series of experiments was intended to measure inherent virulence. This contrasts with experiments in the companion paper by Chintala et al. (2002), in which the measured effects were the combined result of host-defense systems or metabolic condition, and the inherent virulence of the pathogen. The results reported in the present paper demonstrated that parasites freshly isolated from infected hosts were much more virulent than those that had been established in culture. The data did not support our hypothesis that virulence was lost gradually over many passages. Because of this, repassing the parasite through its host to restore virulence of culture lines was not successful for Perkinsus marinus. Results did show, however, that virulence is associated with culture phase: log-phase parasites were significantly more virulent than those obtained from lag- or stationary-phase cultures.

The higher virulence of wild-type parasites was clearly documented in 2 separate experiments that used different oyster cohorts and different Perkinsus marinus isolates. The $P$. marinus isolates, begun at dif- ferent times and using different initiation procedures (i.e. parasites placed directly in culture medium and those incubated in RFTM first), indicated that the large difference in virulence between cultured and wildtype parasites was not limited to a single isolate. In an earlier study, Bushek \& Allen (1996) reported differences in virulence of $P$. marinus isolates from different geographic regions; however, cumulative mortalities over $84 \mathrm{~d}$ in oysters dosed with the 4 isolates tested were very low (10 to $14 \%$ ) and similar to our results for cultured parasites. Thus, despite between-isolate variance, it remains clear that cultured parasites, as a group, are far less virulent than freshly isolated, wildtype parasites.

In most of our experiments, deaths occurred in 2 phases: the first, within $3 \mathrm{wk}$ of dosing and the second, 2 to 6 wk later. Oysters dying earlier tended to die from lighter infections. This 2-phase mortality, particularly evident in oysters dosed with wild-type parasites, parallels changes in parasite densities within the host. Immediately after dosing, parasite densities are relatively high and reflect the inoculum; thereafter, they decline over a period of 1 to several weeks before net proliferation occurs and body burdens begin rising again (Bushek \& Allen 1996, Bushek et al. 2002, this issue). Consequently, oysters dying during the early phase were killed by the initial dose of parasites, probably aggravated by the dosing trauma, since the parasite loads were typically lighter than during the second-phase mortality. During the latter phase, parasites had proliferated to the point at which the infection alone was heavy enough to cause death $\left(10^{6}\right.$ to $10^{7}$ cells $\left.\mathrm{g}^{-1} \mathrm{wwt}\right)$.

The greatest difference between wild-type and cultured Perkinsus marinus was measured during the second mortality phase, which occurred 3 to 6 wk earlier and produced mortalities 5 to 20 times greater in oysters dosed with wild-type cells. It is noteworthy, however, that wild-type parasites also caused higher earlyphase mortality than did cultured parasites. Some element from the original, heavily infected donor oysters that was carried over in the inoculum (including bacteria, although the isolation medium was heavily laced with antibiotics, or toxic metabolites from sick oysters) may have contributed to the elevated early death rate. Alternatively, the wild-type cells may have been secreting potent virulence factors (La Peyre et al. 1995, 1996) at the time they were isolated and injected.

Loss of virulence in culture has been reported for many pathogens. To our knowledge, all such reports show the loss to occur gradually, over several to many passages. For instance, the pathogenicity of the Cux-1 isolate of chicken anemia virus was substantially reduced after 50 to 175 passages (Todd et al. 1995) and 2 bursal-disease viruses lost virulence after 4 passages 
in tissue culture (Hassan et al. 1996). Similarly, Borrelia burgdorferi, the bacterial agent of Lyme disease, lost virulence after 17 to 21 passages (Moody et al. 1990). Protozoans, too, may lose the ability to establish infections after many passages in culture (Chang \& Fish 1983). Sutherland et al. (1996) reported that the protozoan Theileria annulata, which causes tropical theileriosis in cattle, gradually loses virulence when kept in continuous culture. Virulence of the human pathogen Leishmania donovani decreases as a function of time in culture (Mukhopadhyay et al. 1998) as well as from passage to passage (Giannini 1974, Kallinikova et al. 1992).

Our results differed from those cited above in that they showed no evidence of gradual virulence loss after Perkinsus marinus was placed in culture. There was little difference in cumulative mortality or in survivor parasite burdens between oysters injected with cryopreserved parasites from the initial post-isolation culture, or passed cells from the first and ninth passages. The 'immediate-loss' pattern was most apparent in the VI, where there were no statistically significant differences among any groups ( $p>0.05)$. The elevated mortality observed in the Passage 5 trial occurred in all 3 treatments (passed- and cryopreserved-cell injected oysters and uninjected controls) and dead oysters did not have particularly high parasite burdens, suggesting that some aspect of the trial other than the parasite was different. Oysters used for Passage 5 were part of the same batch used for Passage 1, but they had been held in the laboratory at $10^{\circ} \mathrm{C}$ for an additional $6 \mathrm{wk}$ (see Table 1). The appearance of conchiolinous shell deposits in the Passage 5 oysters may indicate some additional stress on these oysters that contributed to the higher mortality. Despite the anomalous results for Passage 5, several points are clear: (1) there was no pattern to the differences among passage trials, (2) mortalities and VI were low for all groups, including the 'pre-passage' cryopreserved cells, and (3) mortalities for these relatively early passage trials were similar to those for the high-passage $(>30)$ culture used in other experiments reported here. Taken together, these results argue that virulence was lost immediately, with no discernible trend thereafter.

One explanation for loss of virulence is that the culture environment fails to induce the production of virulence factors. Although protease secretion has been measured in cultured Perkinsus marinus (La Peyre et al. 1995, 1996), these substances may not be critical virulence factors, or they may not be produced in quantities comparable to wild-type cells. The delay in disease development and host mortality associated with cultured-parasite challenge would reflect the time required for parasites to readjust to the in vivo environment and begin synthesizing the virulence fac- tors again. Similarly, the period after parasites are first introduced into culture before they begin proliferating vigorously could reflect the time required for the parasites to adjust to the in vitro medium. Mukhopadhyay et al. (1998) reported that decreased expression of certain cell-surface molecules coincided with time in culture and infectivity of Leishmania donovani. Based on evidence that at least 1 of these molecules might protect the parasite from intracellular digestion, they hypothesized that in culture, the parasites '...gradually reduce the synthesis of molecules required for their intracellular survival [in the host].' Changes in the proportion of phenotypically distinct viral strains after both in vitro and in vivo passage have also been reported (Faulkner et al. 1976, Potter et al. 1976, Hall et al. 1999, Hare \& McConough 1999). The stimulus to produce virulence factors in $P$. marinus that is missing in vitro could be a metabolite lacking in the culture medium, an inappropriate gas $\left(\mathrm{O}_{2}, \mathrm{CO}_{2}\right)$ pressure (sensu Willson \& Burnett 2000), or some other critical difference between the in vitro and in vivo environments.

Genetic selection is another mechanism that could underlie the loss of virulence in cultured parasites. In the host, virulence is critical to the establishment and maintenance of an infection. The ability to survive host defense mechanisms and to utilize substrates provided by the host are especially important, and unless all parasites used to begin an in vitro culture are from a single clone, there will be genetic variability in these and other traits upon which selection can act. Reece et al. (1997, 2001) provided evidence that multiple Perkinsus marinus clones co-exist within individual oysters. Those clones with the ability to survive and proliferate rapidly in culture would be favored over slower-growing forms, even though the latter might be more virulent and survive better in the host. This selective pressure for avirulent subpopulations has been demonstrated for the protozoa Babesia bovis (Carson et al. 1990), Theileria annulata (Sutherland et al. 1996), and Leishmania major (Kallinikova et al. 1992). If some virulent forms remain in culture, repassage through the host can reverse the process and restore virulence because those parasites producing sufficient virulence factors would survive and proliferate better in the host (Kallinikova et al. 1992).

Many wild-type Perkinsus marinus do not survive, or simply may not reproduce, after being introduced into culture media (Bushek \& Chintala pers. obs.). Similarly, there is a marked loss of parasites from oyster tissue for several weeks after they have been injected, and this loss is more prolonged for cultured than for wild-type parasites (Bushek \& Allen 1996, Bushek et al. 2002). Accordingly, it can be argued that during the transition from an in vivo to an in vitro culture, or in the 
reverse direction, only a fraction of the starting $P$. marinus population survives and proliferates in the new environment. It is likely that the surviving parasites are better adapted to the new environment than those that died. It was not possible for us to determine whether there was a genetic component to the observed phenotypic change in the virulence of $P$. marinus, although it is worth noting that Sutherland et al. (1996) found evidence that both phenotypic and genotypic changes were involved in the gradual loss of virulence in the cattle parasite Theileria annulata maintained in culture.

Repassing cultured parasites through a host to restore virulence in a cell line (Faulkner et al. 1976, Chang \& Fish 1983, Stanley et al. 1994, Todd et al. 1995) did not work for Perkinsus marinus, because the virulence of $P$. marinus is lost as soon as the parasites are established in culture. We did not test virulence of the in vivo-passed parasites before they were reestablished in culture by immediately using them in challenge experiments, but the fact that the lethal density for both wild-type and cultured parasites (including the in vivo-passage experiment) was similar $\left(10^{6}\right.$ to $10^{7}$ parasites $\mathrm{g}^{-1} \mathrm{wwt}$ ) argues that cultured parasites, once inside the oyster, eventually become as virulent as those isolated directly from oysters. If the cultured parasites never regained full virulence in vivo, one might expect that it would take a higher parasite burden to kill an oyster using cultured cells.

Although we found no differences in virulence of Perkinsus marinus associated with time in culture, we did observe differences related to culture phase. Logphase parasites were the only ones to show net proliferation inside the oyster during the $87 \mathrm{~d}$ experiment. Infection intensities resulting from lag-phase cells were the same at the start and end of the experiment, and parasite burdens in oysters injected with stationary-phase cells actually decreased. The VI for the logphase cultures was twice that for the stationary-phase cells, and cumulative mortality was 2 to 3 times greater in the log-phase treatment than in the other 2 groups. Frequency distributions of parasite burdens also supported the evidence that log-phase cells were the most virulent (Chintala et al. 2002). Burdens in many individuals injected with lag- and stationary-phase cells had diminished by the end of the experiment, whereas those in oysters challenged with log-phase cells were equal to, or greater than, the injected dose.

The higher virulence of the log-phase parasites may be attributable to the fact that they were already metabolically and reproductively very active in culture and thus required a somewhat shorter time to begin proliferating in vivo compared to the lag- and stationaryphase parasites. The lag-phase cells had not yet begun to divide rapidly at the time of injection, and the sta- tionary-phase cells contained a component of apparently senescent parasites indicating that cells in this culture phase were metabolically relatively inactive. The link between activity in vitro, and virulence in vivo, suggests that the principal difference among Perkinsus marinus culture phases was probably the proportion of parasites able to proliferate soon after entering the host. It is possible that, had we run a longer challenge trial, parasite loads would have eventually increased to lethal levels in equal numbers of oysters regardless of culture phase.

The greater virulence of more 'active' parasites in the log phase was also suggested in experiments with wild-type parasites. Oysters dosed with wild-type parasites began dying with heavy infections 6 wk earlier in the summer trial than in the autumn trial. This was despite the fact that a relatively larger soft-tissue weight-standardized dose was given in the autumn trial when mantle fluid was considered part of the 'tissue' weight. The speed with which oysters challenged with wild-type cells began dying in the summer trial suggests that parasites isolated in July, when they are rapidly proliferating, may be more virulent than those collected in September, when parasite loads are high and parasite division rates are low (Saunders et al. 1993, Hofmann et al. 1995, Ford et al. 1999).

Alternatively, oysters may have been more susceptible to parasite-induced mortality in the summer, as they died with lower parasite burdens than in the autumn. These oysters may have been weakened by spawning during the first $2 \mathrm{wk}$ of the experiment. A temporary failure of air supply along with fouled water from the spawning could have further compromised the oysters (Chintala et al. 2002). Finally, despite our efforts to purify Perkinsus marinus from naturally infected oysters, and to reduce bacterial loads, there may have been seasonal differences in associated microflora or their toxins introduced with the wild-type inoculations.

Our experiments clearly documented that cultured Perkinsus marinus has relatively low virulence, that virulence is lost as soon as parasites begin proliferating in culture, and that log-phase parasites are the most virulent forms. They also showed an inherently high level of noise from trial to trial, despite a considerable effort to standardize procedures and to use highly susceptible, hatchery-produced oysters from the same source and reared under similar conditions. For instance, log-phase parasites were used in Expts I, III, and IV, yet mortality varied from 8 to $38 \%$ over a $12 \mathrm{wk}$ period. Cryopreserved and passed parasites from the same culture caused mortalities ranging from 5 to $20 \%$ in Expt II. Oysters died with parasite burdens of $10^{6}$ to $10^{7}$ in most trials, but with burdens of around $10^{4}$ in Expt II. The variability suggests that factors other than 
the parasites themselves can significantly affect the outcome of a challenge trial and the measurement of virulence. It is likely that host metabolic condition, in addition to inherent parasite virulence or host resistance, plays an important role in the outcome of the host-parasite interaction (Chintala et al. 2002).

Acknowledgements. We thank J. Gandy, K. Alcox, J. Oxley, I. Eleazar, T. Ferarra, D. Ianniello, L Smith, C. Spruck, and R. Holley for assistance in maintenance of oysters and processing of samples; J. Heltshe for statistical consultation; and S. Benyi, R. Gobell and K. Rocha for critical review of the manuscript. This study was supported by the NOAA Oyster Disease Research Program under grants NA47FL0153 and NA57FL0042. This is publication No. 2001-19 from the Institute of Marine and Coastal Sciences at Rutgers, No. D-324055-01 of the NJ Agricultural Experiment Station, contribution number 1299 of the Baruch Institute for Marine Biology and Coastal Research at the University of South Carolina, and EPA Atlantic Ecology Division contribution number 00-090. Mention of trade names or commercial products does not constitute endorsement or recommendation for use by the US Environmental Protection Agency. Although this research has been funded in part by the US Environmental Protection Agency, it has not been subjected to Agency review. Therefore, it does not necessarily reflect the views of the Agency.

\section{LITERATURE CITED}

Abacus Concepts (1994) Survival tools for StatView. Abacus Concepts, Berkeley, CA

Andrews JD (1961) Measurement of shell growth in oysters by weighing in water. Proc Natl Shellfish Assoc 52:1-11

Andrews JD, Hewatt WG (1957) Oyster mortality studies in Virginia. II. The fungus disease caused by Dermocystidium marinum in oysters of Chesapeake Bay. Ecol Monogr $27: 1-26$

Bricelj VM, Ford SE, Borrero FJ, Perkins FO, Rivara G, Hillman RE, Elston RA, Chang J (1992) Unexplained mortalities of hatchery-reared, juvenile oysters, Crassostrea virginica (Gmelin). J Shellfish Res 11:331-347

Burreson EM, Ragone Calvo LM, La Peyre JF, Counts F, Paynter KT (1994) Acute osmotic tolerance of cultured cells of the oyster pathogen Perkinsus marinus (Apicomplexa: Perkinsida). Comp Biochem Physiol A 109:575-582

Bushek D (1994) Dermo disease in the American oyster. Genetics of host-parasite interactions. PhD dissertation, Rutgers University, New Brunswick, NJ

Bushek D, Allen SK Jr (1996) Host-parasite interactions among broadly distributed populations of the eastern oyster Crassostrea virginica, and the protozoan Perkinsus marinus. Mar Ecol Prog Ser 139:127-141

Bushek D, Ford SE, Allen J, SK (1994) Evaluation of methods using Ray's fluid thioglycollate medium for diagnosis of Perkinsus marinus infection in the eastern oyster, Crassostrea virginica. Annu Rev Fish Dis 4:201-217

Bushek D, Allen SK, Alcox KA, Gustafson R, Ford SE (1997) Response of Crassostrea virginica to in vitro cultured Perkinsus marinus: preliminary comparison of three inoculation methods. J Shellfish Res 16:479-485

Bushek D, Holley RA, Reece KS (2000) Use of micromanipulation and 'feeder' cultures to clone the protozoan oyster pathogen Perkinsus marinus. J Eukaryot Microbiol 47: 164-166
Bushek D, Ford SE, Chintala MM (2002) Comparison of in vitro-cultured and wild-type Perkinsus marinus. III. Fecal elimination and its role in transmission. Dis Aquat Org $51: 217-225$

Carson CA, Timms P, Cowman AF, Stewart NP (1990) Babesia bovis-evidence for selection of subpopulations during attenuation. Exp Parasitol 70:404-410

Chang KP, Fish WR (1983) Leishmania. In: Jensen JB (ed) In vitro cultivation of protozoan parasites. Press, Boca Raton, FL, p 111-153

Chintala MM, Bushek D, Ford SE (2002) Comparison of in vitro-cultured and wild-type Perkinsus marinus. II. Dosing methods and host response. Dis Aquat Org 51: 203-216

Choi KS, Wilson EA, Lewis DH, Powell EN, Ray SM (1989) The energetic cost of Perkinsus marinus parasitism in oysters. Quantification of the thioglycollate method. J Shellfish Res 8:117-125

Chu FLE, Volety AK (1997) Disease processes of the parasite Perkinsus marinus in eastern oyster Crassostrea virginica: minimum dose for infection initiation, and interaction of temperature, salinity, and infective cell dose. Dis Aquat Org 28:61-68

da Silva R, Sacks D (1987) Metacyclogenesis is a major determinant of Leishmania promastigote virulence and attenuation. Infect Immun 55:2802-2806

Dungan CF, Hamilton RM (1995) Use of a tetrazolium-based cell proliferation assay to measure effects of in vitro conditions on Perkinsus marinus (Apicomplexa) proliferation. J Eukaryot Microbiol 42:379-388

Faulkner P, Potter K, Jaques RP (1976) Modification of virulence of nuclearpolyhedrosis virus following serial passage in vivo. Proc Int Colloq Invertebr Pathol 1:18-19

Fisher WS, Oliver LH (1996) A whole-oyster procedure for diagnosis of Perkinsus marinus disease using Ray's fluid thioglycollate culture medium. J Shellfish Res 15:109-117

Ford SE, Schotthoefer A, Spruck C (1999) In vivo dynamics of the microparasite Perkinsus marinus during progression and regression of infections in eastern oysters. J Parasitol 85:273-282

Freshney RI (1987) Culture of animal cells: a manual of basic technique. Wiley-Liss Publishers, New York, NY

Gauthier JD, Vasta G (1993) Continuous in vitro culture of the eastern oyster parasite Perkinsus marinus. J Invertebr Pathol 62:321-323

Gauthier JD, Vasta GR (1995) In vitro culture of the eastern oyster parasite Perkinsus marinus: optimization of the methodology. J Invertebr Pathol 66:156-168

Giannini MS (1974) Effects of promastigote growth phase, frequency of subculture, and host age on promastigoteinitiated infections with Leishmania donovani in the golden hamster. J Protozool 21:521-527

Hall R, Ilhan T, Kirvar E, Wilkie G, Preston PM, Darghouth M, Somerville R, Adamson R (1999) Mechanism(s) of attenuation of Theileria annualta vaccine cell lines. Trop Med Int Health 4:A78-A84

Hare JM, McConough KA (1999) High-frequency RecAdependent and -independent mechanisms of Congo red binding mutations in Yersinia pestis. J Bacteriol 181: 4896-4904

Hassan MK, Alnatour MQ, Ward LA, Saif YM (1996) Pathogenicity, attenuation and immunogenicity of infectious bursal disease virus. Avian Dis 40:567-571

Hofmann EE, Powell EN, Klinck JM, Saunders G (1995) Modelling diseased oyster populations. I. Modelling Perkinsus marinus infections in oysters. J Shellfish Res 14:121-151

Kallinikova VD, Nasyrova RM, Nayrov FS, Safjanova VM 
(1992) Morphogenesis and virulence of Leishmania major in the process of long-term cultivation. Arch Protistenkd 141:327-334

Kleinschuster SJ, Swink SL (1993) A simple method for the in vitro culture of Perkinsus marinus. Nautilus 107:76-78

La Peyre JF, Chu FL (1994) A simple procedure for the isolation of Perkinsus marinus merozoites, a pathogen of the eastern oyster, Crassostrea virginica. Bull Eur Assoc Fish Pathol 14:101-103

La Peyre JF, Faisal M (1995) An improved method for the initiation of continuous culture of the oyster pathogen Perkinsus marinus (Apicomplexa). Trans Am Fish Soc 124: 144-146

La Peyre JF, Faisal M, Burreson EM (1993) In vitro propagation of the protozoan Perkinsus marinus, a pathogen of the eastern oyster, Crassostrea virginica. J Eukaryot Microbiol 40:304-310

La Peyre JF, Schafhauser DY, Rizkalla EM, Faisal M (1995) Production of serine proteases by the oyster pathogen Perkinsus marinus (Apicomplexa) in vitro. J Eukaryot Microbiol 42:544-551

La Peyre JF, Yarnell HF, Faisal M (1996) Contribution of Perkinsus marinus extracellular products in the infection of eastern oysters (Crassostrea virgninica). J Invertebr Pathol 68:312-313

Mackin JG, Boswell JL (1955) The life cycle and relationships of Dermocystidium marinum. Proc Natl Shellfish Assoc 46: 112-115

Mackin JG, Sparks AK (1962) A study of the effect on oysters of crude oil loss from a wild well. Publ Inst Mar Sci Univ Tex 7:230-261

Mackin JG, Owen HM, Collier A (1950) Preliminary note on the occurrence of a new protistan parasite, Dermocystidium marinum n. sp. in Crassostrea virginica (Gmelin). Science 111:328-329

Moody KD, Barthold SW, Terwilliger GA (1990) Lyme borreliosis in laboratory animals: effect of host species and in vitro passage of Borrelia burgdorferi. Am J Trop Med Hyg 43:87-92

Mukhopadhyay S, Sen P, Majumder H, Roy S (1998) Reduced expression of lipophosphoglycan (LPG) and kinetoplastid membrane protein (KMP)-11 in Leishmania donovani promastigotes in axenic culture. J Parasitol 84:644-647

Osterhout S (1999) Host-parasite relationships. In: Joklik WK, Willett HP, Amos DB, Wilfert CM (eds) Zinsser microbiology. Appleton \& Lange, Norwalk, CT, p 387-392

Potter K, Faulkner P, MacKinnon EA (1976) Strain selection during serial passage of Trichoplusia ni nuclear polyhedrosis virus. J Virol 18:1040-1050

Editorial responsibility: Albert Sparks, Seattle, Washington, USA
Ray SM (1952) A culture technique for the diagnosis of infections with Dermocystidium marinum. Mackin, Owen and Collier, in oysters. Science 166:360-361

Ray SM (1954) Biological studies of Dermocystidium marinum, a fungus parasite of oysters. Rice Institute, Houston, TX

Reece KS, Bushek D, Graves JE (1997) Molecular markers for population genetic analysis of Perkinsus marinus. Mol Mar Biol Biotechnol 6:197-206

Reece KS, Bushek D, Hudson KL, Graves JE (2001) Geographic distribution of Perkinsus marinus genetic strains along the Atlantic and Gulf coasts of the USA. Mar Biol 139:1047-1055

Rey JA, Travi BL, Valencia AZ, Saravia NG (1990) Infectivity of the subspecies of the Leishmania braziliensis complex in vivo and in vitro. Am J Trop Med Hyg 43:623-631

SAS Institute (1990) SAS language: reference, Version 6, 1st edn. SAS Institute, Cary, NC

Saunders GL, Powell EN, Lewis DH (1993) A determination of in vivo growth rates for Perkinsus marinus, a parasite of Crassostrea virginica. J Shellfish Res 12:229-240

Stanley LA, Hudson JS, Schwedler TE, Hayasaka SS (1994) Extracellular products associated with virulent and avirulent strains of Edwardsia ictaluri from channel catfish. J Aquat Anim Health 6:38-43

Sutherland IA, Shiels BR, Jackson L, Brown DJ, Brown CGD, Preston PM (1996) Theileria annulata: altered gene expression and clonal selection during continuous in vitro culture. Exp Parasitol 83:125-133

Tanada Y, Fuxa JR (1987) The pathogen population. In: Fuxa JR, Tanada Y (eds) Epizootiology of insect diseases. WileyInterscience, New York, p 113-157

Todd D, Connor TJ, Calvert VM, Creelan JL, Meehan BM, McNultry MS (1995) Molecular-cloning of an attenuated chicken anemia virus isolate following repeated cellculture passage. Avian Pathol 24:171-187

Valiulis GA, Haskin HH (1972) Resistance of Crassostrea virginica to Labyrinthomyxa marina. Proc Natl Shellfish Assoc 63:6

Willson LL, Burnett LE (2000) Whole animal and gill tissue oxygen uptake in the eastern oyster, Crassostrea virginica: effects of hypoxia, hypercapnia, air exposure, and infection with the protozoan parasite Perkinsus marinus. J Exp Mar Biol Ecol 246:223-240

Wozencraft O, Blackwell JM (1987) Increased infectivity of stationary-phase promastigotes of Leishmania donovani: correlation with enhanced C3 binding capacity and CR3mediated attachment to host macrophages. Immunology 60:559-563

Submitted: December 8, 2000; Accepted: February 12, 2002 Proofs received from author(s): August 28, 2002 